Jurnal Ilmu Sosial dan Pendidikan (JISIP)

Vol. 6, No. 1 Januari 2022

e-ISSN : 2656-6753, p-ISSN: 2598-9944

DOI: 10.36312/ jisip.v6i1.2637/http://ejournal.mandalanursa.org/index.php/JISIP/index

\title{
Makna Pertunjukan Kesenian Gendang Beleq Pada Masyarakat Sasak Kontemporer (Desa Bujak Kecamatan Batukliang Lombok Tengah)
}

\author{
Andika Apriawan ${ }^{1}$, Muhammad Zoher Hilmi ${ }^{2}$ \\ ${ }^{1}$ Dosen Pendidikan Sosiologi, UNU NTB, Bujak - Batukliang, Lombok Tengah NTB, Indonesia \\ ${ }^{2}$ Dosen Pendidikan Sosiologi, Sepit - Jerowaru, Lombok Timur NTB, Indonesia
}

\begin{abstract}
Article Info
Article history:

Received 23 November 2021

Publish 01 Januari 2022
\end{abstract}

Keywords:

Kesenian Gendang Beleq;

Sasak Kontemporer;

Desa Bujak.

\section{Info Artikel}

Article history:

Diterima 23 November 2021

Publis 01 Januari 2022

\begin{abstract}
Abstrak
Kesenian merupakan salah satu peninggalan dari suatu kebiasaan-kebiasaan yang terjadi di waktu lampau dan diteruskan pada masa sekarang. Salah satu pertunjukan kesenian yang masih dilestarikan oleh masyarakat Suku Sasak khsusnya di Desa Bujak adalah kesenian Gendang Beleq.Pertunjukan kesenian gendang beleq pada masyarakat suku sasak menarik untuk diteliti karena eksistensinya yang masih dapat dipertahankan sampai saat ini, meskipun telah mengalami perubahan konteks masyarakat pada awal penggunaannya. Berdasarkan penelitian terdaulu bahwa gendang beleq digunakan oleh kerajaan untuk mengiringi prajurit berangkat perang guna untuk membangkitkan semanganya, beda halnya dengan sekarang pertunjukan kesenian gendang beleq digunakan pada upacara hajatan masyarakat sasak khususnya di Desa Bujak. Hal itu tidak terlepas dari makna luhur yang tekandung di dalamnya, hingga sampai saat ini masih mentradisi dan melekat erat menjadi salah satu komponen dalam system sosial hidup masyarakat. Berangkat dari sinilah penulis tertarik untuk mendalami apa sebenarnya makna yang masih relevan atas pertunjukan kesenian gendang beleq pada masyarakat sasak kontemporer, padahal dapat disadari bahwa sudah tidak ada lagi peperangan yang membutuhkan tabuhan gendang beleq. Metode yang digunakan dalam penelitian ini adalah penelitian kualitatif dengan pendekatan penomenologi, yang mana peneliti menjadi instrument kunci (human instrument). Teknik pengumpulan data dalam penelitian ini adalah melaksanakan kegiatan Focus Group Discussion (FGD) bersama para pimpinan sanggar kesenian gendang beleq yang ada di Desa Bujak, melakukak observasi, melakukan wawancara mendalam, dan mengumpulkan dokumendokumen pendukung lainnya yang bisa memberikan petunjuk dan penjelasan terkait dengan makna pertunjukan kesenian gendang beleq. Data yang didapatkan dalam penelitian ini akan dianalisis dengan teknik reduksi, penyajian, dan verifikasi data.Hasil penelitian in menunjukan bahwa makna pertunjukan kesenian gendang beleq bagi masyarakat Desa Bujak kontemporer adalah dimaknai sebagai pembentuk sikap sabar, lebih patuh dan teratur. Selain itu juga kesenian gendang beleq dimaknai sebagai penekanan identitas kesukuan yang lahir dann dibesarkan di temapt yang sama yaitu Suku Sasak Lombok. Pemaknaan lain juga sebagai spirit persatuan dan gotong royong dalam kehidupan bermsyarakat.
\end{abstract}

This is an open access article under the Lisensi Creative Commons AtribusiBerbagiSerupa 4.0 Internasional

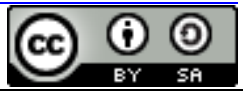

\section{Corresponding Author:}

Andika Apriawan

Dosen Pendidikan Sosiologi, UNU NTB, Bujak - Batukliang, Lombok Tengah NTB, Indonesia

Email: andika.apriawan@gmail.com, 


\section{PENDAHULUAN}

Eksistensi kehidupan sosial masyarakat Indonesia tidak bisa lepas dari budaya yang di dalamnya masih tersimpan nilai-nilai sosial dan filosofis sebagai energi dalam menjalani kehidupan. Bahkan banyak norma kehidupan diadopsi dari nilai-nilai kebudayaan yang tersebar di seluruh wilayah Negara Kesatuan Republik Indonesia. Sehingga perilaku masyarakat Indonesia baik secara individu maupun kelompok mencerminkan kebijaksanaan yang didasari oleh nilai-nilai pada budaya tertentu.

Masih banyak tradisi kebudayaan di Indonesia yang dapat dilestarikan dan dijalankan oleh masyarakatnya sampai saat ini meski dihadapkan dengan arus perubahan sosial yang pesat. Semuanya itu menandakan bahwa sesungguhnya tradisi dalam suatu budaya masyarakat sulit untuk dipisahkan dari masyarakat itu sendiri karena alasan-alasan tertentu. Tradisi kebudayaan masyarakat memang menjadi salah satu komponen sistem sosial kehidupan masyarakat sehingga dengan demikian cukup menjadi landasan kuat dilestarikannya suatu tradisi kebudayaan tertentu dalam masyarakat sejak dulu hingga sekarang bahkan untuk masa yang akan datang.

Gendang Beleq adalah salah satu tradisi kesenian budaya masyarakat suku sasak di Lombok Nusa Tenggara Barat. Sebagai sebuah tradisi kebudayaan, keberadaanya masih tetap dilestariakn sampai saat ini, hal ini tentu ada alasan masyarakat yang kuat berdasarkan beberapa sudut pandang yang bisa diamati secara langsung. Sebagai salah satu contoh bahwa pertunjukan kesenian Gendang Beleq bagi masyarakat suku Sasak khususnya masyarakat di Desa Bujak sangat fungsional bagi suatu peristiwa sosial tertentu sehingga dengannya dapat terjalin kehidupan sosial kemasyarakatan yang baik.

Pertunjukan kesenian gendang beleq di Desa Bujak mendapat apresiasi yang tinggi oleh masyarakat. Bahkan di Desa Bujak dapat ditemukan tiga sanggar kesenian gendang beleq yang masih aktif sampai sekarang yang tersebar di beberapa wilayah Desa Bujak, yaitu sanggar "Jati Swara" di Dusun Gunung Amuk sebagai refresentasi wilayah Bujak bagian utara, sanggar "Bajang Angen" di Dusun Gunung Petung sebagai refresentasi wilayah Bujak bagian Selatan, dan Sanggar "Jati Darmajaya" di Dusun Tin Petuk sebagai refresentasi wilayah Bujak bagian timur.

Keberadaan ketiga sanggar kesenian gendang beleq dan tingginya apresiasi yang diberikan oleh masyarakat Desa Bujak merupakan bentuk pelestarian terhadap kesenian tersebut. Bentuk apresiasi yang diberikan oleh masyarakat dapat diamati dari penggunaan gendang beleq oleh masyarakat pada suatu acara tertentu, misalnya acara begawe (hajatan) pernikahan dan khitanan, meskipun ada juga golongan masyarakat yang tidak senang dengan pertunjukan kesenian gendang beleq.

Begawe (hajatan) pernikahan maupun khitanan merupakan peristiwa sosial yang di dalamnya diramaiakan dengan pertunjukan kesenian gendang beleq. Apresiasi masyarakat Desa Bujak terhadap pertunjukan kesenian gendang beleq dihubungkan dengan antusiasme masyarakat mengikuti dan membantu atau dengan istilah lain gotong royong mengerjakan serangkaian aktivitas yang dilakukan pada acara hajatan tersebut merupakan menjadi sebuah perilaku sosial. Sehingga hal itu menurut penulis pertunjukan kesenian gendang beleq ini yang dapat mempengaruhi perilaku sosial itu penting untuk diteliti lebih dalam. Mengingat kesenian gendang beleq pada mulanya digunakan untuk membangkitkan semangat juang para prajuit kerajaan masa lampau, sementra sampai saat ini pertunjukan kesenian gendang beleq masih tetap dilestarikan di tengah-tengah kehidupan masyarakat.

Pertanyaannya kemudian bagaimana sebenarnya masyarakat sasak kontemporer memaknai pertunjukan kesenian gendang beleq, padahal konteks sosial saat ini yang sudah jauh berbeda dengan kondisi pada awal mula penggunaan gendang beleq? Berdasarkan pertanyaan ini penulis tertarik melakukan penelitian secara mendalam untuk mengetahuinya secara lebih detil. 


\section{METODE PENELITIAN}

Penelitian ini merupakan penelitian kualitatif deskriptif, yang akan mendeskripsikan fenomena dan gejala sosial yang terjadi dalam masyarakat dengan menggunakan pendekatan fenomenologi. Peneliti akan menjelaskan makna pertunjukan kesenian gendang beleq sebagai musik tradisional yang mana eksistensinya masih dilestarikan samapai saat ini meskipun dihadapi dengan tantangan zaman modern yang membawa perubahan perilaku masyarakat.

\section{HASIL DAN PEMBAHASAN}

Kesenian merupakan salah satu peninggalan dari suatu kebiasaan-kebiasaan yang terjadi di waktu lampau dan diteruskan pada masa sekarang. Salah satu kesenian yang masih dilestarikan oleh masyarakat suku sasak khsusnya di Desa Bujak adalah kesenian Gendang Beleq.

Gendang beleq merupakan seni musik yang tergolong dalam ansambel yang terdiri dari: Gendang Mame, Gendang Nine, Cemprang, Perembaq, Petug, Oncer, Rincig, Reong Mame, ReongNine, Gong Mame, dan Gong Nine, Seluruh intrstrumen-instrumen Gendang Beleq tersebut bekerja secara seimbang saling menutupi dan saling melengkapi. Pada masa lampau kesenian gendang beleq digunakan sebagai iring-iringan raja dan para prajurit kerajaan Mataram Lombok saat hendak menjalankan tugas kerajaan yaitu berlaga di medan perang, dan sepulangnya pun disambut dengan tabuhan gendang beleq. Hal ini berdasarkan cerita masyarakat suku Sasak bahwa gendang belek sebagai penggugah semangat juang untuk memenangkan peperangan melawan musuh kerajaan.

Kesenian gendang beleq merupakan alat musik kebanggaan masyarakat Sasak ini dimainkan dengan cara ditabuh dan dimainkan secara berkelompok. Gendang beleq yang terdiri dari dua kata merupakan penggabungan Bahasa Indonesia dan Sasak. "Beleq" dari bahasa Sasak berarti besar. Ada dua buah gendang beleq yang disebut gendang mama (laki-laki) dan gendang nina (perempuan), berfungsi sebagai pembawa dinamika. Gendang beleq biasa dimainkan bersamaan dengan alat musik lainnya seperti gong, terumpang, pencek, oncer, dan seruling. Dengan suara yang ramai, pertunjukan gendang beleq sangat meng-hibur.

a. Perkembangan Kesenian Gendang Beleq Pada Masyarakat Desa Bujak

Kesenian merupakan salah satu peninggalan dari suatu kebiasaan-kebiasaan yang terjadi di waktu lampau dan diteruskan pada masa sekarang. Kebiasaan-kebiasan inilah yang kemudian menimbulkan lahirnya kesenian tradisional yang banyak berkembang di desa dan di masing-masing pulau. Kemudian merupakan salah satu unsur atau elemen kebudayaan pada umumnya, perkembangan kesenian mengikuti berubahnya suatu kebudayaan masyarakat yang sudah menjadi kenyataan bahwa kesenian sebagai salah satu unsur kebudayaan yang tidak lepas dari kebudayaan itu.

Sesuai dengan perkembangan zaman, bahwa kesenian gendang beleq pada masyarakat suku sasak di pulau Desa Bujak mengalami perkembangan yang pesat. Akhirakhir ini pertunjukan kesenian gendang beleq tengah mengalami perluasan yang mana pertunjukannya dihajatkan untuk mengiringi pengantin, acara khitanan dan juga untuk menyambut tamu kehormatan baik pada acara non formal maupun acara formal pemerintahan. Bahkan tidak berlebihan gendang beleq dijadikan sebagai salah satu ikon pembangunan daerah di provinsi Nusa Tenggara Barat. Sebagai ikon pembangun daerah provinsi Nusa Tenggara Barat kesenian gendang beleq tidak jarang tampil di media promosi pariwisata daerah yang digalakan oleh pemerintah. Bahkan kesenian gendang beleq dipertunjukan pada acara kancah nasional dan internasional yang diihadiri oleh kepala Negara dan tamu luar negeri lainnya. Pada tahun 2013 sanggar gedang beleq Jati Swara Gunung Amuk Desa Bujak pernah dikirim ke Jakarta sebagai penghibur pada acara salah satu partai (Wawanacara, 26 Mei 2021).

Perekembangan kesenian gendang beleq pada masayarakat suku sasak khususnya di Desa Bujak juga dapat diamati di lembaga pendidikan, yang mana terdapat salah satu lembaga pendidikan yang memuat kesenian Gendang Beleq dalam kurikulumnya. Berdasarkan hasil observasi di SMPN 4 Batukliang dapat ditemukan sanggar kesenian 
Gendang Beleq sebagai salah satu unit kegiatan ekstrakurikuler siswa. Keberadaan sanggar Gendang Beleq di satuan sekolah ini diakui sebagai wadah formal untuk melestarikan kesenian Gendang Beleq. Lebih jauh dari itu juga berdasarkan hasil wawancara dengan Kepala SMPN 4 Batukliang mengakui bahwa kesenian Gendang Beleq sebagai refresentasi potret kehidupan masyarakat Desa Bujak yang masih gemar dengan kesenian tersebut.

Sanggar ini menjalin kemitraan dengan sanggar gendang beleq Jati Swara dalam rangka untuk memberikan pelatihan bagi para siswa yang memiliki minat untuk mempelajari kesenian gendang beleq. Pada sanggar ini para siswa diberikan bekal pengetahuan tentang sejarah awal kegunaan gendang beleq di masa lampau dan diberikan pelatihan mengaransmen berbagai alat musik kesenian gendang beleq yang terdiri dari gendang yang berukuran besar, menjadi tabuhan yang menghasilkan bunyi-bunyian irama dan gerakan yang dapat menceritakan perilaku dan karakter masyarakat suku sasak.

Musik gendang beleq di Lombok khususnya di Desa Bujak masih di budidayakan sebagai salah satu musik tradisional yang tidak dapat di geser atau dihapus meskipun tengah perubahan zaman yang begitu cepat, semakin kesini gendang beleq diajarkan kepada para remaja Desa Bujak khususnya di Dusun Gunung Amuk, Tilawah, dan Tin Petuk supaya remaja mempunyai rasa cinta terhadap musik gendang beleq dan tidak meninggalkan apa yang telah di tinggalkan oleh nenek moyang mereka. Sesuai dengan berkembangnya kesenian pada saat ini gendang beleq sangat digemari oleh semua masyarakat suku Sasak karena lebih menarik dari pada sebelumya dan mampu mempersatukan kelompok yang satu dengan kelompok yang lain. Akan tetapi pada sekarang ini gendang beleq juga sudah mulai kehilangan identitasnya karena pulau Lombok sudah di masuki oleh warga asing yang mengakibatkan tradisi ini ada penyesuaian akan tetapi dapat mempersatukan masyarakat dengan semua perbedaan. Akan tetapi di sisi lain kesenian musik gendang beleq juga dapat mengubah masyarakat pada tingkat evolusi sosial yang mengakibatkan timbulnya masyarakat industri di mana manusia menjadi bersifat lebih individualis dan di mana kekuasaan raja dan keyakinan terhadap raja keramat berkurang maka timbul lagi suatu sistem hukum yang baru, yang kembali berdasarkan atas azas saling butuh membutuhkan antara warga masyarakat secara timbal balik.

b. Makna Pertunujukan Kesenian Gendang Beleq Pada Masyarakat Desa Bujak .

Bagi masyarakat suku Sasak khususnya masyarakat Desa Bujak mengakui bahwa perkembangan zaman modern menjadi salah satu tantangan yang berarti dalam pelestarian kesenian gendang beleq. Namun, kegemarannya menggunakan kesenian gendang belek masih tergolong tinggi di tengah banyaknya jenis kesenian lain yang tidak terlahir dari kebudayaan asli masyaraakat suku Sasak. Hal kongkrit yang dilakukan oleh masyarakat Desa Bujak sebagai upaya pelestarian kesenian gendang beleq adalah adanya penolakan penggunaan kesenian selain gendang beleq, misalkan kesenian kecimol ataupun kesenian lain yang telah mengadopsi konsep modern. Penolakan yang dilakukan masyarakat dengan cara tidak langsung yaitu memberikan kesan kurang mendukung terhadap acara gawe yang apabila diiringi oleh selain kesenian gendang beleq. Sehingga dengan demikian dapat mempengaruhi perilaku masyarakat dalam hal ini cara menentukan jenis kesenian yang akan digunakan oleh pemilik hajatan atau istilah masyarakat suku sasak yaitu gawe.

Melihat phenomena di atas dengan mengacu pada system nilai budaya bahwa masyarakat Desa Bujak sejujurnya tengah berupaya menjaga nilai-nilai yang terkandung dalam budaya kesenian gendang beleq. Mengutip Jacobus Ranjabar bahwa nilai yang menjadi unsur dalam kebudayaan itulah yang menghendaki masyarakat mendorong dan mengharuskan warganya untuk menghayati dan mengamalkan nilai yang dianggapnya ideal. Selanjutnya dilihat dari segi waktu menurut Clyde Kluckhohn, nilai agak abadi, sehingga dengan demikian nilai merupakan suatu standar yang mengatur serta mengelola sejumlah system kelakuan (2016: 116).

Nilai yang terkandung dalam budaya tradisional yang berhubungan dengan kesenian gendang beleq pada pulau Lombok suku Sasak menurut Anderson (Dalam Runi Fazalani, 
2020:259) gendang beleq dalam bayangan manusia Sasak memiliki makna yang luhur yaitu musik gendang beleq memiliki beberapa makna, antara lain:

1)Nilai filosofis.

Melestarikan gendang beleq dimaknai manusia Sasak sebagai menata dan memelihara diri sendiri, karena di dalam musik gendang beleq terkandung keindahan, ketelitian, ketekunan, kesabaran, kebijakan dan kepahlawanan. Berdasar penilaian ini, musik gendang beleq bagi orang Sasak dianggap sakral. Musik ini tidak mungkin ada tanpa nilai-nilai filosofis tersebut difahami terlebih dahulu oleh nenek moyang Sasak. Mereka mentradisikannya agar difahami oleh keturunan mereka dan dipelajari muatannya.

Hal ini sejalan dengan apa yang disampaikan oleh Sanusin (Kepala Sanggar Gendang Beleq Jati Swara) bahwa memainkan kesenian gendang beleq membawa pengaruh terhadap sikap pemain, cenderung lebih sabar, lebih patuh dan teratur. Selain pemain, para penikmat juga menjadi spirit untuk bergotong royong sebagai bentuk makna dari kepahlawanan. Dengan kesenian gendang beleq juga mampu mennimbulkan solidaritas sosial.

2)Nilai psikologis.

Keterikatan satu imajinasi yang sama, yaitu sama-sama manusia Sasak yang memiliki berbagai kesamaan, seperti nenek moyang, geografis, budaya bahkan mungkin agama.

Gendang beleq dipersepsikan sebagai sebuah identitas masyarakat suku sasak, sehingga perilaku sosial masyarakat sampai saat saat menggunakan gendang beleq picu oleh kesadaran bersama bahwa sesama anak suku sasak yang tinggal dan besar di wilayah geografis serta dari rahim nenek moyang yang sama pula. Bahkan yang lebih ekstram banyak yang membangun stigma bahwa identitas kesasakannya tidak sempurna bila tidak menggunakan kesenian gendang beleq.

3)Nilai sosiologis.

Seni musik gendang beleq dapat menjadi ajang untuk interaksi sosial yang terbuka tanpa sekat status sosial, pendidikan, atau keturunan. Dalam hal ini Sanusin mengatakan bahwa para pemain setelah mengenakan pakaian khas akan memnimbulkan sikap yang menegedapankan kesetaraan, tidak ada sikap saling membeda-bedakan peran baik dari segi usia maupun pendidikan, mengingat para sekahe (pemain) terdiri dari berbagai latar belakang yang berbeda-beda. Hal ini pula dapat dilihat dari para pengiring pengantin yang terdiri dari muda-mudi mengenakan pakain khas Lombok yang sama. Lebih lanjut Ia mengatakan bahawa pertunjukan kesenian gendang beleq memiliki nilai-nilai integrasi dan equlaiy. Nilai integrasi dapat dilihat dari perilaku masyarakat yang bersatu padu dengan penuh semangat bergotong royong menunjukan peran dan fungsinya pada acara gawe saat ditabuhnya gendang beleq. Selain itu ada nilai yang sangat berarti bagi masyarakat yaitu kesetaraan antara masyarakat berdarah biru (bangsawan) dengan masyakat biasa (jajar karang), yang mana dengannya membuka semua berbaur mengenakan dodot (kain songket), sapuk (ikat kepala), bebat (ikat pinggang), dan membawa keris (wawancara, 19 Mei 2021). Pertunjukan kesenian gendang beleq juga sering dimaknai sebagai ajang bagi muda-mudi untuk mengenal dan mencari jodoh, tidak sedikit mereka akhirnya menikah setelah berkenalan ketika bersama menonton gendang beleq.

\section{KESIMPULAN}

Kesenian merupakan salah satu peninggalan dari suatu kebiasaan-kebiasaan yang terjadi di waktu lampau dan diteruskan pada masa sekarang. Salah satu kesenian yang masih dilestarikan oleh masyarakat suku sasak khsusnya di Desa Bujak adalah kesenian Gendang Beleq. Pada masa lampau kesenian gendang beleq digunakan sebagai iring-iringan raja dan para prajurit kerajaan Mataram Lombok saat hendak menjalankan tugas kerajaan yaitu berlaga di medan perang, dan sepulangnya pun disambut dengan tabuhan gendang beleq. Hal ini 
berdasarkan cerita masyarakat suku Sasak bahwa gendang belek sebagai penggugah semangat juang untuk memenangkan peperangan melawan musuh kerajaan.

Pada masayarakat kontemporer makna pertunjukan kesenian gendang beleq bermakna (1) nilai filosofis, memainkan kesenian gendang beleq membawa pengaruh terhadap sikap pemain, cenderung lebih sabar, lebih patuh dan teratur. Selain pemain, para penikmat juga menjadi spirit untuk bergotong royong sebagai bentuk makna dari kepahlawanan. Dengan kesenian gendang beleq juga mampu mennimbulkan solidaritas sosial. Nilai psikologis. Keterikatan satu imajinasi yang sama, yaitu sama-sama manusia Sasak yang memiliki berbagai kesamaan, seperti nenek moyang, geografis, budaya bahkan mungkin agama. (2) makna psikologis gendang beleq dipersepsikan sebagai sebuah identitas masyarakat suku sasak, sehingga perilaku sosial masyarakat sampai saat saat menggunakan gendang beleq picu oleh kesadaran bersama bahwa sesama anak suku sasak yang tinggal dan besar di wilayah geografis serta dari rahim nenek moyang yang sama pula. Bahkan yang lebih ekstram banyak yang membangun stigma bahwa identitas kesasakannya tidak sempurna bila tidak menggunakan kesenian gendang beleq. (3) makna sosiologis. Seni musik gendang beleq dapat menjadi ajang untuk interaksi sosial yang terbuka tanpa sekat status sosial, pendidikan, atau keturunan..

\section{SARAN}

Saran menggambarkan hal-hal yang akan dilakukan terkait dengan gagasan selanjutnya dari pengabdian tersebut. Hambatan-hambatan atau permasalahan yang dapat mempengaruhi hasil pengabdian juga disajikan pada bagian ini.

\section{UCAPAN TERIMA KASIH}

Ucapan terima kasih terutama ditujukan kepada pemberi dana pengabdian atau donatur. Ucapan terima kasih dapat juga disampaikan kepada pihak-pihak yang membantu pelaksanaan pengabdian.

\section{DAFTAR PUSTAKA}

https://www.materipelajaran.web.id/2017/02/tradisi-gendang-beleq.html (diakses pada tanggal 25 Oktober 2020

Jazuli, M. 2014. Sosiologi Seni Edisi 2 Pengantar dan Model Studi Seni. Yogyakarta: Graha Ilmu.

Nur Kholis Sumardi, Evolusi Gendang Beleq, Jurnal Seni dan Budaya 2017

Ritzer, G. 2014. Teori Sosiologi Modern. Terjemahan. Jakarta: Kencana Prenadamedia Group

Rosana, E. 2011. Modernisasi dan Perubahan Social. Jurnal TAPIs, 7 (12): 31-47.

Runi Fazalani. 2020. Kesenian Gendang Belek Masyarakat Suku Sasak Sebagai Budaya Tradisional. journal.um-surabaya.ac.id Lingua Franca: Jurnal Bahasa, Sastra, dan Pengajarannya.

Sugiyono. 2012. Metode Penelitian Pendidikan Pendekatan Kuantitatif, Kualitatif, dan R\&D. Bandung: Alfabeta.

Sulasman, H dan Gumilar, S. 2013. Teori-Teori Kebudayaan dari Teori Hingga Aplikasi. Bandung: Pustaka Setia. 